\title{
Development of a Tool for Assessing the Design Process: A step toward the creation of a Design Observatory
}

\author{
S. Gendron ${ }^{1}$, J. Brousseau ${ }^{2}$, A. Elouafi ${ }^{2}$, B. Urli $^{1}$ \\ ${ }^{1}$ Management Sciences Department \\ ${ }^{2}$ Mathematics, Information Technology, and Engineering Department \\ Université du Québec à Rimouski (UQAR), Rimouski, QC (Canada)
}

\section{Summary}

An exploratory survey, conducted in 2010, has led to a better understanding of the design practices of Québec businesses located in the Bas-Saint-Laurent, Gaspésie, Îles-de-la-Madeleine, and Côte-Nord regions. This survey was conducted among 31 businesses from different sectors of activity focused on design methods, tools and techniques.

The study shows, among other things, that most businesses claim to use a structured design process, although a very few resort to structured methods, sophisticated tools, or specialized design techniques. The results seem to indicate that the design process of SME located in the Lower Saint-Lawrence Area is not as organized as it could be expected.

To understand the determinants of design performance better, and to develop indicators for assessing the design process, a new research has been launched.

A conceptual model, derived from a review of literature, was selected to develop the indicators. Three axes (environmental, human and technoscientific knowledge) and three aspects (organisation, processes and features of the product) are identified and used to define the design system.

The research aims to develop a method and a tool to assess and characterize an organization, its design system and its design process. The results will serve to establish an observatory of the design practices. Such an observatory will contribute to improve the engineering design education.

\section{Introduction}

Good design practices are key factors of innovation and competitiveness of companies. Furthermore, the companies that are investing more in design increase their annual sales and gain a better access to new markets [3].

Educational institutions in engineering have the imperative responsibility to implement programs for the purpose of developing design knowledge [2].
Knowledge on best practices for designing is, however, almost non-existent. Therefore, in order to improve the training of future engineers, it becomes essential to learn more about design practices.

It is in light of this context that emerged the idea to conduct an exploratory study on the subject. The original goals were to learn more about the practices of design in companies located in the territory served by UQAR and to identify new ideas to improve our engineering programs.

The objective of this article is to present the main results of the survey as well as its current trend. This evolution includes a new research project on the development of performance indicators in the design and the creation of an observatory on design practices.

\section{A Portrait of Designing}

The survey has helped to develop a portrait of design practices in companies located within the region of influence of UQAR. This exploratory type of survey sought to understand the context in which design is practiced in companies likely to employ graduates of Engineering Programs.

The survey also aimed at getting to know better the companies with which partnerships are developed for student training through the implementation of concrete design projects.

\subsection{Sample}

In the winter of 2010, 31 companies responded to a questionnaire distributed to 80 companies from different sectors of activities. The latter were particularly questioned on R\&D, design support and their design practices. Among all respondents, $42 \%$ were already partners of the project-based courses of the engineering programs.

For comparison purpose, the companies surveyed were grouped according to three types of organizations: Professional Services (7), Manufacturers (21), and Producers/Distributors (3).

Respondents to the survey include organizations 
with annual sales ranging from less than $\$ 100 \mathrm{k}$ to more than $\$ 100000 \mathrm{k}$, and that employ 1 to 500 people. The larger companies $(100$ or more employees) are also those who earnt the most in annual sales (more than $\$ 10 \mathrm{M}$ ). Table 1 illustrates the percentage of respondents per class of annual sales and the average number of employees of the companies included in these classes.

Table 1. Annual Sales and Number of Employees

\begin{tabular}{|l|r|r|}
\hline ANNUAL SALES & \multicolumn{1}{|c|}{$\begin{array}{l}\text { \% } \\
\text { REP }\end{array}$} & $\begin{array}{l}\text { № OF } \\
\text { EMPLOYEE } \\
\text { S }\end{array}$ \\
\hline Less than $\$ 100 \mathrm{k}$ & 3.2 & 1.0 \\
\hline \$100k to $\$ 500 \mathrm{k}$ & 9.7 & 7.0 \\
\hline \$500k to $\$ 1 \mathrm{M}$ & 6.5 & 7.5 \\
\hline \$1M to $\$ 3 \mathrm{M}$ & 22.6 & 61.6 \\
\hline \$3M to $\$ 5 \mathrm{M}$ & 16.1 & 73.0 \\
\hline \$5M to $\$ 10 \mathrm{M}$ & 16.1 & 62.0 \\
\hline \$10M to $\$ 25 \mathrm{M}$ & 9.7 & 127.0 \\
\hline \$25M to $\$ 30 \mathrm{M}$ & 3.2 & 325.0 \\
\hline \$50M to $\$ 100 \mathrm{M}$ & 9.7 & 333.3 \\
\hline More than $\$ 100 \mathrm{M}$ & 3.2 & \\
\hline Total & 100.0 & \\
\hline
\end{tabular}

The majority of respondents is composed of small and medium-size businesses. It is noted that $54.8 \%$ are fond in a range between 1 and $\$ 10 \mathrm{M}$ in annual sales. No company has declared employing more than 500 employees.

\subsection{Main results}

It was noted that the investment in $R \& D$ per employee decreases with the size of the company. It has been observed also that R\&D teams as well as design teams are usually small ( 2 to 3 persons).

Among the organizations surveyed, $38 \%$ state that they develop, each year and at once, new products, new processes, and new specialized equipments.

Concerning the number of engineers, $31 \%$ of the companies do not have one, $31 \%$ employ only one, and $15 \%$ employ either 2 or 3 . Table 2 illustrates the results and the percentage of employees represented by engineers.
Table 2. Number of Engineers by Companies

\begin{tabular}{|l|c|c|}
\hline $\begin{array}{l}\text { NNo OF } \\
\text { ENG. }\end{array}$ & $\begin{array}{c}\text { \% } \\
\text { REP }\end{array}$ & $\begin{array}{l}\text { \% OF № OF } \\
\text { EMPLOYEES }\end{array}$ \\
\hline 0 & 30.8 & 0 \\
\hline 1 & 30.8 & 0.7 \\
\hline 2 & 15.3 & 3.0 \\
\hline 3 & 15.3 & 9.5 \\
\hline $15+$ & 7.7 & 18.5 \\
\hline Total & 99.9 & \\
\hline
\end{tabular}

As regards to the methods of design, it appears that $60 \%$ of the organizations surveyed state that they use a structured design process to progress from the idea level to the prototype and product. Figure 1 indicates, among other things, that $40 \%$ of the manufacturers state that they do not have a design process.

Figure 1. Use of a Structured Design Process

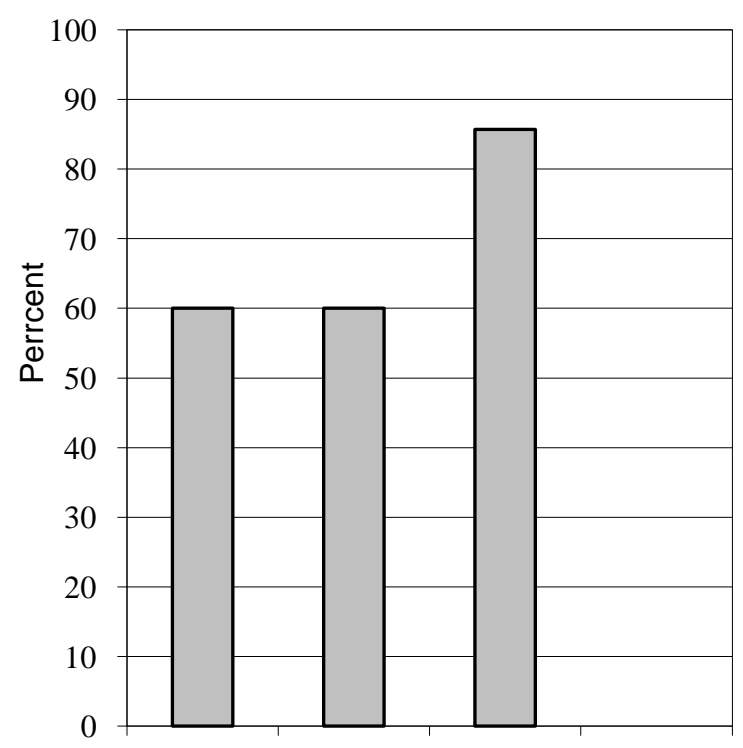

All Manufacturers Services Prod./Dist.

It was found that manufacturers earning between $\$ 0.1 \mathrm{M}-\$ 25 \mathrm{M}$ in annual sales include $40 \%$ of those stating that they do not use any design process. Conversely, companies earning more than $\$ 25 \mathrm{M}$ in annual sales all use a design process.

As a whole, the use of design Methods, Tools and Techniques (MTT) is found only in $27 \%$ of the respondents, particularly among the larger manufacturers. Figure 2 illustrates the percentage of respondents who use MTT such as Design for Manufacturing \& Assembly, Lean Design, etc. 
Figure 2. Use of Design MTT

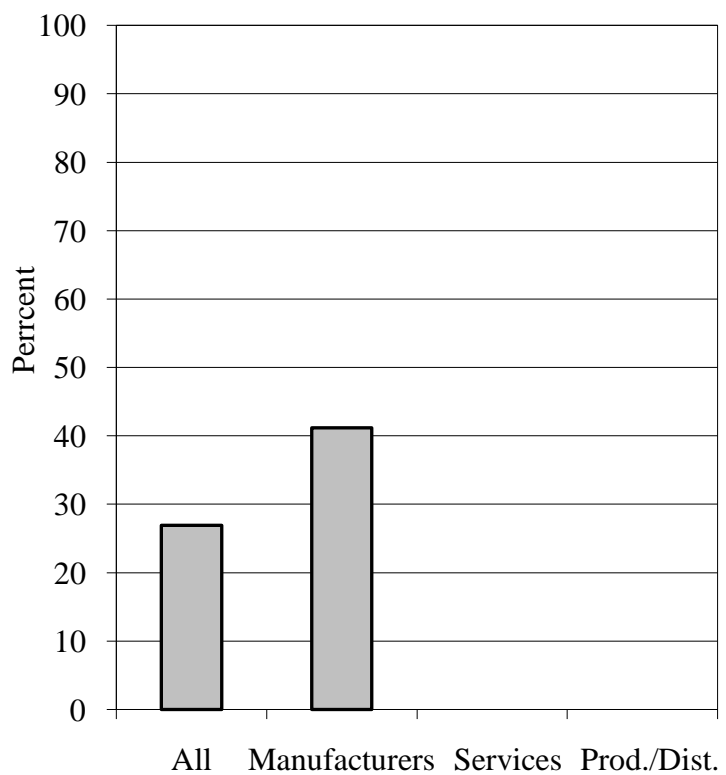

There is a gap between the fact of declaring the use of a structured design process, and on the other hand, the use of MTT. For most respondents, the gap is 33\% between the use of a structured design process and the use of MTT.

Among respondents, the gaps between the existence of a process and the use of MTT shows well in business categories under $\$ 50 \mathrm{M}$. For most respondents, the gap is $50 \%$ for the under $\$ 1 \mathrm{M}$ in annual sales category and $28.4 \%$ in the $\$ 1 \mathrm{M}-\$ 10 \mathrm{M}$.

The use of design MTT stems from a reasoned approach, aimed at productivity. The results seem to indicate that the design process used by a company uses is not as structured as it could, particularly among small manufacturers, since a design process benefits from being complemented by the design MTT and that several companies do not use them.

It appears that the design culture is almost nonexistent among the small organizations that were consulted during this survey.

\subsection{Observation and Continuity}

Notwithstanding the results presented, this survey has allowed the collecting of meaningful data on the realities the design process in the region such as:

- The use of design software;

- The acquisition of production facilities;

- Production management;

- The number of trainees hired;

- $\quad$ The lack of skilled labour;

- The use of R\&D assistance programs;

- Partnerships with institutions;
- The influence of the Chair; and

- Design projects for the students.

As regards to the latter results, this survey was not aimed at assessing design performance. That is why we cannot judge the adequacy of the use of design MTT in relation to the design process used and the results sought by a company. However, this Design Portrait has generated the idea of a new study and a new survey.

\section{A New Research Project}

To better understand design practices in companies likely to employ engineering graduates, a research project was launched in the fall of 2010. The goal of this new research is to identify ways to improve the existing industrial design culture and engineering design education.

This new research project consists of a study whose aim is to contribute to the development of a tool for characterizing and evaluating design practices. One of its specific objectives is to identify the performance indicators of the design process.

An inductive approach was adopted to carry out this new research project. Case studies of individual companies involved with design will help to formulate generalizations, or even to develop new hypotheses, particularly on the appropriate variables required to measure design performance. Given the number of variables to be measured, and the exploratory nature of the mandate, the sample should total at least 30 participants.

The research builds on knowledge relating to the field of design. A review of literature on the subject supports the development of a questionnaire intended to measure the variables that characterize design practices and influence their performance.

The questionnaire will ask some questions previously used for the 2010 Winter Survey for characterization purposes. Before being used for the purposes of this research, the questionnaire will be tested and refined on a pilot basis. However, the approach will be different and the variables will be evaluated by project managers according to their degree of importance on the success of design projects. To do this, the evaluation will be based on the Likert Scaling method comprising seven grades (essential to the success $=6$, no influence on the success $=0$ ).

The specifications for this research are also descriptive in part, since the data will be analyzed to show the relationship between variables and to identify those that contribute the most to the success of the design projects. 
The data collected will be analyzed using various techniques of factorial analysis such as the principal components method. The analysis will let us identify the most important factors, thus leading to the development of design performance indicators. The latter will evaluate the various dimensions of a design project. They will allow for the assessment of design performance based on best practices.

Once the variables that influence the success have been identified, the factors compounded, a new questionnaire (measurement tool) intended for a greater number of companies could be developed. This questionnaire would constitute the basis for a longitudinal research, entrusted to either a research body or to an observatory of design practices.

\subsection{Literature Review}

Within the framework of this new research, a literature review was conducted in order to establish the conceptual bases of the design performance.

At first glance, this literature review shows that design is driven by different motives [4], and that it is derived from a context that imposes adaptations and innovations [14][17]. We can then see that according to various sectors of activities, practices and the benefits attributed to design somewhat vary [4][15].

The literature review allowed us to specify the concepts related to designing in engineering and in particular, that of the design process [1][11][12][13][19][20]. It permitted to choose a model that suits the characterization and evaluation of the design practices [14][18]. The lines that follow depict some of the elements of this review.

\subsubsection{Design Investment Drivers}

The competition context forces the companies to be proactive and to anticipate the evolution of technologies. That is why companies must not only control the quality, the cost and the time limit for introducing their products on the market, but also, their flexibility and responsiveness [14].

Within this context, companies must, among other things, focus their attention on the optimization of their technologies and of their manufacturing processes but also of their design methods [17].

For North American companies, the evolution of the client's preferences and the shrinking of delays in marketing are the main drivers of investing in design, but one might also mention the increase in capacity and performance of products and technology [4].

\subsubsection{Design and Sectors of Activities}

The goals and the benefits that stem from the adoption of advanced technologies and processes in design differ according to the sectors of activities.

For example, among the manufacturers of low technological intensity, where innovation is rather focused on improving the product, the impact of technologies for product development over innovation is high [15].

However, in sectors of concentrated technology, characterized by a short life cycle of products and by highly competitive companies, the impact of product $\mathrm{R} \& \mathrm{D}$ over innovation is more important than the impact of technologies for the development of the product [15].

It has been observed that the adoption of advanced technologies in product design, such as $\mathrm{CAD}$, virtual prototyping and rapid prototyping is more frequent and timely in some sectors of activity than others [4].

Similarly, the use of a design process such as concurrent engineering is seen more frequently in those sectors of activity where various decision makers are involved in the design process as this approach facilitates the optimization of the many parameters of the design as performance and the manufacturing cost of the product [4].

\subsubsection{Design Process}

There are many definitions of the design process [3]. However, it can be defined as a set of activities implemented (in a sequential and/or parallel manner) using the human and material resources to meet the design objectives and lead to the definition of the product [14].

Although the design is difficult to model because of its cognitive dimension [6], several descriptions of the design process have been proposed [8].

As such, we can quote the models developed using the phase concept such as those of Pahl and Beitz [11], Pugh [12], Ulrich and Eppinger [20], Ulman [19].

These models emphasize the need to plan the evolution of the product by having a overview ranging from the global level to the very detailed level. The phase concept considers the stages of the design process as being temporarily staked and a priori defined by hierarchical planning [14].

There is also an approach of the design process based on activities. Table 3 offers two descriptions of the design process according to this approach. The concept of activity shows task performance on the part of the actors in the process. The process description is based on a splitting of the temporal sequence of design 
activities and is organized in elements of action (actor or group assigned to a goal).

Table 3. Activities of the design process

\begin{tabular}{|l|}
\hline The Purcell MODEL [13] (Purcell, 94) \\
\hline - Analyzing Problem. \\
- Proposing Solution \\
- Analyzing Solution. \\
- Explicit Strategies. \\
\hline The Ahmed MODEL [1] (Ahmed, 02) \\
\hline - Specifying \\
- Evaluating \\
- Validating \\
- Navigating \\
- Unifying \\
- Deciding \\
\hline
\end{tabular}

\subsubsection{Choice of a Conceptual Model}

The design process is a group of organized activities set to meet the design objectives of a specific context. These objectives relate primarily to the definition of the product. They are dependent on the structure of the company [10] and the various activities of the design process. The objectives are also influenced by technology and by human and physical resources [21].

Depending on the type of design, the subjects of the design are different. When the process becomes routine, the project leader plans the project according to the identified activities and then the tasks of the designers are relatively prescribed [14][18]. In such cases, observance of the delay period becomes the most important performance objective to achieve. The project manager decides on the synchronization between the human and material resources available and the needs of activities.

In other cases, the design is regarded as a creative process. The activities do not structure the project [18]. The project is then organized to promote collaboration between the actors in order to facilitate the emergence of solutions.

Many models of project description have been proposed [5][7][9] and a synthesis of the different approaches [18] shows that to describe the context in which the design process evolves, one must consider the human aspects, scientific and technological knowledge, and the socio-economic and organizational environment. The representation of this synthesis is illustrated in figure 1.
Figure 1. Conceptual Model of the Design System

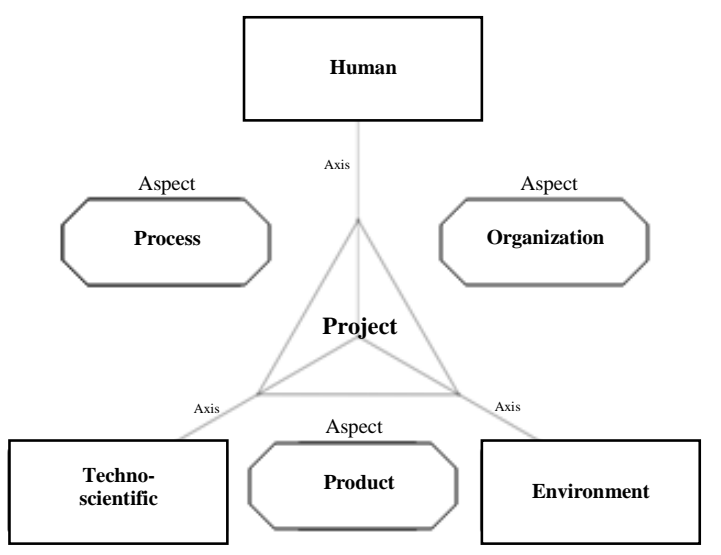

In this model, the internal and external environment axis represents the company and its environment.

The human axis is represented by the human resources involved in the project.

The techno-scientific knowledge axis corresponds to the knowledge and the technologies already in place in the company.

To take into account the interactions between the axis of a design project, it is proposed to apprehend them by intermediate aspects, that being the product, the process, and the organization.

The product aspect is found between the environment and knowledge axis because it is the product that demonstrates the knowledge and the technology and that proves that the company can perform on the market.

The process aspect is found between knowledge and human since it is by the process (phases and activities) that the actors transform knowledge into a product with such or such characteristic.

The organizational aspect is found between the environment and the human axis since at the organizational level, the management of a design project reflects in the allocation of resources and by the institution of an organization adapted to the situation.

\subsection{OPERATIONALIZATION}

The axis and the aspects must be characterized. The questionnaire aims at identifying the important factors and at developing performance indicators.

For the environment, it is important to know the sector of activity, the characteristics of the market, the size of the company and its network. The measured variables should constitute the environmental factor of a design project. 
As for the human axis, it is about knowing the players involved, their skills, their responsibilities, their roles, and their availability. These variables should match the human factor.

The techno-scientific axis will be characterized by the leading-edge technologies used in design, and by the $R \& D$, the capitalization of knowledge and the areas of expertise of the company. These variables will constitute the techno-scientific factor.

The organizational aspect will be described as a function of the management of the design project, that is to say the management structure put in place, the planning, allocation of resources, the follow-ups and controls. These variables will constitute the technoscientific factor.

The process will be described by using a list of phases and activities arising from the existing models and by means of MTT. These variables will constitute the process factor.

The product will be characterized by its complexity, its technical degree, and its innovative character in order to constitute the product factor.

The questionnaire will be used to collect information on the design systems of the company and to measure the importance of different variables on the success of design projects. Thus, it will be possible to map the design system and to identify the variables and the overriding factors.

Since the sector of activity influences the design practice, the surveyed companies will be selected from 5 sectors of activity, and the sample will target companies recognized for the quality of their products and their leadership.

\section{Toward a Design Observatory}

This final point deals with the establishment of a design practice observatory within companies. The research project presented in the above section and the implantation of the observatory will contribute to the development of a tool for characterizing and evaluating the design process. The observatory will ensure the refinement of the tool developed in the research project and will be able to provide data for related research. be:

Specifically, the objectives of this observatory will

- To Follow the evolution of design practices in companies;

- $\quad$ To Improve the training offered by teaching and act on the determinants;

- $\quad$ To Develop diagnostic tools; and

- To Support the continuous improvement of the design processes in companies.
The conceptual model of this observatory is established. It will be based on the three dimensions and three aspects that allow the characterisation of the design system specific to each company.

The observatory will play a role at the structural level by providing information to the players such as the participating companies, educational institutions, and economic development agencies.

At the human resources level, the observatory will promote the development of design expertise in future engineers, ensuring that the contents of the programs are tailored to the needs of design and that the skills acquired by the engineers in training do benefit companies. In addition, it will contribute to the appropriation of the design culture among the actors through targeted interventions.

Finally, the observatory will play a strategic role in initiating a synergy between the companies and the actors of development in regard to design. In so doing, it will foster the development of partnerships for support purposes in order to improve design performances and to assist in the consolidation and development of participating companies.

With its dual capacity of collecting data and supporting the development of expertise, the observatory will allow, in the long term, for obtaining a database related to design practices for a large number of companies. The observatory will then be able to support the decision-making process in regional and national actors when the time comes to make their strategic decisions.

\section{References}

[1] P.K. Ahmed, K.K. Lim, M. Zairi, "Measurement practice for knowledge management", Journal of Workplace Learning, Vol.11, $\mathrm{N}^{\circ}$ 8, pp. 304-311, 1999.

[2] CEAB: Canadian Engineering Accreditation Board, Accreditation criteria and procedures, 2007.

[3] D. Deneux, "Méthodes et Modèles pour la conception concourrante", Habilitation à Diriger des Recherches, Université de Valenciennes et du Hainaut Cambrésis, 24 Jan 2002.

[4] DESIGN EXCHANGE en collaboration avec Manufacturiers et exportateurs du Canada et Industrie Canada, "L’ÉTAT de la CONCEPTION DE PRODUITS: LE RAPPORT CANADIEN 2010”, 2010.

[5] E. Eder, "Integration of theories to assist practice", 5th International Conference on Integrated Design and Manufacturing in Mechanical Engineering, IDMME04, Bath, 2004. 
[6] J.S. Gero, "An approach to the analysis of design protocols”, Design studies, Vol. 19, Nº1, pp. 21-61, 1998.

[7] H. Laurikkala, E. Puustinen, E. Pajarre, K. Tanskanen, "Reducing complexity of modelling in large delivery projects", 13th International Conference on Engineering Design, ICED01, Glasgow, 2001.

[8] T. Love, "Philosophy of design: a meta-theoretical structure for design theory”, Design Studies, Vol. 21, №3, pp. 293-313, 2000.

[9] F. Marle, "Modèles d'informations et méthodes pour aider à la prise de décision en management de projet" Thèse Ecole Centrale de Paris, 2002.

[10] H. Mintzberg, Le management : voyage au centre des organisations, Les Éditions d'Organisation, 1989.

[11] G. Pahl, and W. Beitz, Engineering Design - A Systematic Approach, Springer, New York, USA, 1996.

[12] S. Pugh, Total design, integrated methods for successful product engineering, Addison-Wesley, 1990.

[13] T. Purcell, J. Gero, H. Edwards, E. Matka, "Design fixation and intelligent design aids", in Artificial Intelligence in Design, J.S.Gero and F. Sudweeks (ed.), Kluwer, 1994.

[14] V. Robin, "Évaluation de la performance des systèmes de conception pour la conduite de l'ingénierie des produits ; prototype logiciel d'aide aux acteurs", Thèse doctorale, Université Bordeaux 1, École des sciences doctorales des sciences physiques et de l'ingénieur, 2005.
[15] L. Raymond, J. St-Pierre, "La R\&D en tant que déterminant de l'innovation dans les PME : Essai de clarification empirique", Retour aux communications, $5^{\mathrm{e}}$ Congrès International de l'Académie de l'Entreprenariat, 2007.

[16] G. Sohlenius, "Concurrent Engineering", Annals of the CIRP, Vol. $\mathrm{N}^{\circ} 41,1992$

[17] J.C. Tarondeau, Stratégie Industrielle, Vuibert, Paris, 1993.

[18] G. Topliceanu G., V. Robin, C. Ispas, P. Girard, "Évaluation de la performance des processus collaboratifs en conception de produits", U.P.B. Sci. Bull., Series D, Vol. $N^{\circ}$ 72, Iss. 3, 2010

[19] D. Ullman, The Mechanical Design Process, McGrawHill, Inc., New York, NY, 1992.

[20] K.T. Ulrich, S.D. Eppinger, Product design and development, $2^{\text {nd }}$ edition, McGraw Hill International editions, 2000.

[21] F. Wang, J.J. Mills, V. Devarajan, "A conceptual approach managing design resource", Computers in

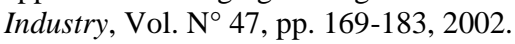




\title{
Enquête exploratoire des pratiques de conception dans les entreprises : une étape vers la création d'un observatoire
}

\author{
S. Gendron ${ }^{1}$, J. Brousseau ${ }^{2}$, A. Elouafi ${ }^{2}$, B. $\operatorname{Urli}^{1}$ \\ ${ }^{1}$ Département des sciences de la gestion, \\ ${ }^{2}$ Département de mathématiques informatique et génie, \\ Université du Québec à Rimouski, Rimouski, QC (Canada)
}

\section{Résumé}

Une enquête exploratoire, menée en 2010, a permis de mieux connaître les pratiques de conception d'entreprises situées dans l'Est du Québec. Cette enquête, réalisée auprès de 31 entreprises de différents secteurs d'activité, portait sur la $R \& D$, les moyens déployés pour appuyer la conception ainsi que sur les méthodes, outils et techniques de conception.

Cette étude montre que les entreprises affirment majoritairement utiliser un processus de conception structuré bien que peu d'entre elles recourent à des méthodes, des outils ou des techniques de conception.

Afin de mieux comprendre les déterminants de la conception et d'identifier les indicateurs de performance du processus de conception, une nouvelle recherche a été lancée.

Un modèle conceptuel, tiré d'une revue de littérature, a été choisi pour développer les indicateurs. Trois axes (environnemental, humain, techno-scientifique) définissent le système de conception. Entre ces axes se situent trois aspects : celui de l'organisation, du processus de conception et des caractéristiques des produits en conception. Les axes et les aspects seront évalués par différentes variables afin d'identifier les facteurs qui influencent la réussite des projets de conception, de même que les variables qui les composent.

Cette recherche contribue à développer un outil de caractérisation et d'évaluation du processus de conception. L'implantation d'un observatoire des pratiques de la conception permettra d'affiner cet outil et aura entre autres objectifs de suivre l'évolution des pratiques de conception en entreprise et d'améliorer la formation offerte en enseignant les façons d'agir sur les facteurs déterminants.

\section{Introduction}

Les pratiques de conception constituent des facteurs clés de l'innovation et de la compétitivité des entreprises. Aussi, les entreprises qui investissent davantage en conception améliorent leur chiffre d'affaires et accèdent mieux aux nouveaux marchés d'exportation [3].

Les institutions d'enseignement en génie ont la responsabilité de mettre en place des programmes devant impérativement développer la compétence en conception [2]. Le savoir relatif aux pratiques de conception est cependant peu abondant. Aussi, afin d'améliorer la formation des futurs ingénieurs, il devient primordial de mieux connaître les pratiques de conception.

C'est dans ce contexte qu'est apparue l'idée de conduire une étude exploratoire sur le sujet. L'objectif de départ était de mieux connaître les pratiques de conception technique dans les entreprises sises sur le territoire que dessert l'UQAR.

L'objectif de cet article est de présenter les principaux résultats de cette enquête ainsi que les suites qui lui sont apportées. Ces suites consistent en un nouveau projet de recherche portant sur le développement d'indicateurs de performance en conception et en la création d'un observatoire des pratiques de conception.

\section{Portrait de la conception}

L'enquête réalisée a permis de dresser un portrait des pratiques de conception en vigueur dans des entreprises localisées dans la région d'influence de l'UQAR. Cette enquête de type exploratoire visait à mieux connaitre le contexte dans lequel se pratique la conception dans des entreprises susceptibles d'employer des finissants des programmes de génie.

L'enquête visait aussi à mieux connaître les entreprises avec qui des partenariats sont développés pour la formation d'étudiants via la réalisation de projets concrets de conception.

\section{1 Échantillon}

À l'hiver 2010, 31 entreprises ont répondu à un questionnaire distribué auprès de 80 entreprises de différents secteurs d'activité. Celles-ci ont été interrogées particulièrement sur la $R \& D$, le support à la conception et sur leurs méthodes de conception. 
Parmi les répondants, $42 \%$ étaient partenaires de l'UQAR.

Pour fin de comparaison, les répondants ont été regroupés selon 3 types d'organisation, soit : les entreprises de services (7), les fabricants (21) et les producteurs-distributeurs (3).

Les répondants de l'enquête comprennent des organisations faisant entre moins de $100 \mathrm{k} \$$ et plus de $100000 \mathrm{k} \$$ de chiffre d'affaires et qui emploient de 1 à 500 personnes. Les entreprises les plus importantes (100 employés et plus) sont aussi celles qui réalisent les plus gros chiffres d'affaires (plus de 10 millions). Le tableau 1 présente le pourcentage de répondants par classe de chiffre d'affaires ainsi que le nombre moyen d'employés des entreprises incluses dans ces classes.

Tableau 1. Chiffre d'affaires et nombre d'employés

\begin{tabular}{|l|r|r|}
\hline $\begin{array}{l}\text { CHIFFRE } \\
\text { D'AFFAIRES EN \$ }\end{array}$ & \multicolumn{1}{c|}{$\begin{array}{c}\text { R } \\
\text { REP }\end{array}$} & $\begin{array}{l}\text { NBR } \\
\text { EMPLOYÉS }\end{array}$ \\
\hline Moins de $100 \mathrm{k}$ & 3,2 & 1,0 \\
\hline $100 \mathrm{k}$ à $500 \mathrm{k}$ & 9,7 & 7,0 \\
\hline $500 \mathrm{k}$ à 1 M & 6,5 & 7,5 \\
\hline $1 \mathrm{M}$ à 3 M & 22,6 & 61,6 \\
\hline $3 \mathrm{M}$ à 5 M & 16,1 & 73,0 \\
\hline $5 \mathrm{M}$ à 10 M & 16,1 & 62,0 \\
\hline $10 \mathrm{M}$ à 25 M & 9,7 & 127,0 \\
\hline $25 \mathrm{M}$ à 30 M & 3,2 & 325,0 \\
\hline $50 \mathrm{M}$ à 100 M & 9,7 & 333.3 \\
\hline Plus de 100 M & 3,2 & - \\
\hline Total & 100,0 & \\
\hline
\end{tabular}

La majorité des répondants est constituée de petites et de moyennes entreprises. On note que $54,8 \%$ sont situés dans un intervalle compris entre 1 et 10 millions de dollars de chiffre d'affaires. Aucune entreprise n'a déclaré employer plus de 500 employés.

\subsection{Principaux résultats}

Il a été remarqué une baisse du pourcentage investi en R\&D par employé plus l'entreprise est importante. Il a été observé que les équipes de R\&D de même que les équipes de conception sont généralement petites ( 2 à 3 personnes).

En ce qui concerne le nombre d'ingénieurs, $31 \%$ des entreprises n'en possèdent pas, $31 \%$ n'en ont qu'un et $15 \%$ en emploient soit 2 ou 3. Le tableau 2 illustre ses résultats et rapporte le pourcentage d'employés que les ingénieurs représentent.

Tableau 2. Nombre d'ingénieurs dans les entreprises

\begin{tabular}{|l|c|c|}
\hline $\begin{array}{l}\text { NBR } \\
\text { INGS }\end{array}$ & $\begin{array}{c}\text { \% } \\
\text { REP }\end{array}$ & $\begin{array}{l}\text { \% DU NBRE } \\
\text { D'EMPLOYÉS }\end{array}$ \\
\hline 0 & 30,8 & 0 \\
\hline 1 & 30,8 & 0,7 \\
\hline 2 & 15,3 & 3,0 \\
\hline 3 & 15,3 & 9,5 \\
\hline 15 et plus & 7,7 & 18,5 \\
\hline Total & 99,9 & \\
\hline
\end{tabular}

Parmi les organisations sondées, $38 \%$ disent développer, chaque année, à la fois, des nouveaux produits, des nouveaux procédés et des nouveaux équipements spécialisés.

En ce qui concerne les méthodes de conception, il appert que $60 \%$ des organisations interrogées disent utiliser un processus de conception structuré pour passer de l'idée à la réalisation concrète. La figure 1 montre entre autres que $40 \%$ des fabricants disent ne pas posséder de processus de conception.

Figure 1. Utilisation d'un processus de conception structuré

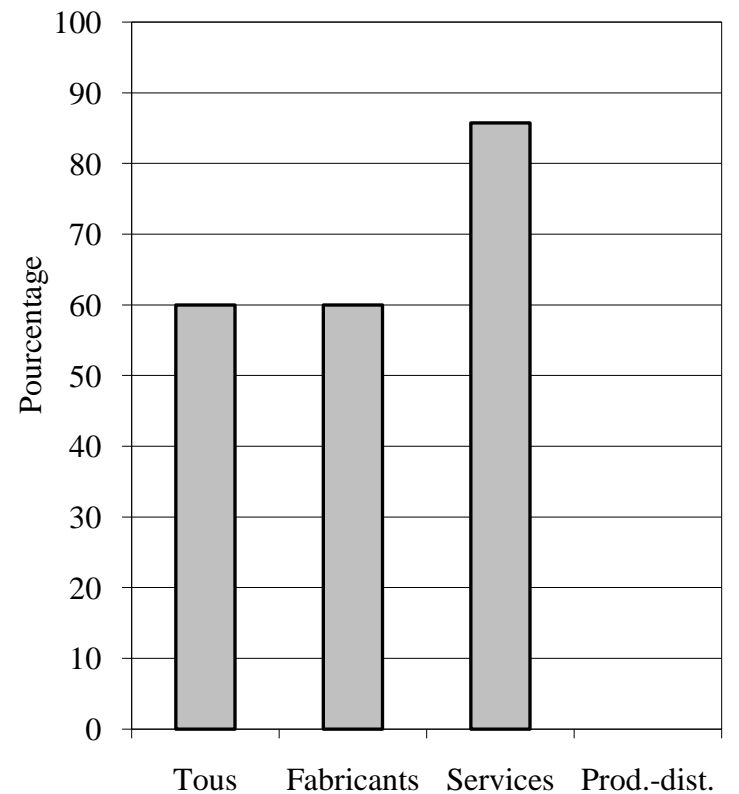

Il a été constaté que les fabricants situés entre 0,1 et $25 \mathrm{M}$ de $\$$ de chiffre d'affaires regroupent les $40 \%$ de ceux qui disent ne pas utiliser de processus de conception. Cependant, les entreprises faisant audessus de $25 \mathrm{M}$ de $\$$ de chiffre d'affaires en utilisent toutes. 
Dans l'ensemble, l'utilisation de méthodes, outils et techniques de conception (MOT) ne se rencontre que chez $27 \%$ des répondants et surtout chez les plus gros fabricants. La figure 2 illustre le pourcentage de répondants ayant recours à des MOT tels que Design For Manufacturing \& Assembly, Lean Design, etc.

Figure 2. Utilisation de MOT de conception

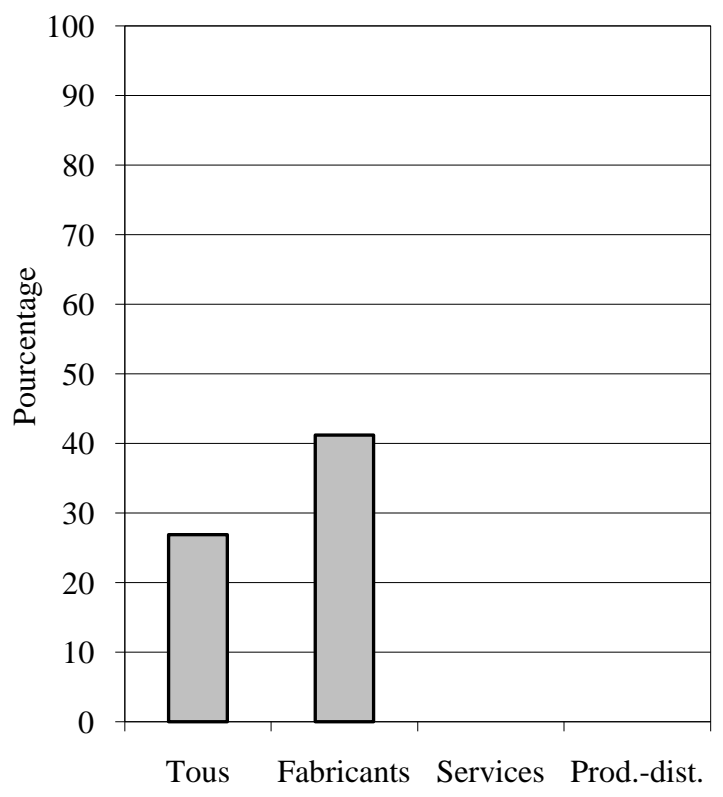

Il existe un écart entre le fait de déclarer utiliser un processus de conception structuré et, d'autre part, employer des MOT. Pour l'ensemble des répondants, l'écart est de $33 \%$ entre l'utilisation d'un processus de conception structuré et le recours à des MOT.

Chez les répondants, les écarts entre la présence d'un processus et l'emploi de MOT sont présents dans les classes d'affaires sous les $50 \mathrm{M}$ de $\$$ et ils sont importants. Pour l'ensemble des répondants, l'écart est de $50 \%$ pour la classe sous $1 \mathrm{M}$ de $\$$ de chiffre d'affaires et de $28,4 \%$ dans la classe de chiffre d'affaires de 1 à $10 \mathrm{M}$ de $\$$. Dans la classe de $10 \mathrm{M}$ à $50 \mathrm{M}$ de $\$$, bien que $75 \%$ des entreprises disent utiliser un processus de conception structuré, aucune n'a dit utiliser de MOT.

Le recours à des méthodes, outils et techniques de conception découle d'une approche raisonnée et orientée vers la productivité. Les résultats semblent indiquer que le processus de conception qu'une entreprise utilise n'est pas aussi structuré qu'il le pourrait, notamment chez les petits fabricants, puisqu'un processus de conception gagne à être accompagné de l'utilisation de MOT de conception et que plusieurs entreprises n'y ont pas recours.

Il apparait que la culture de la conception semble peu présente chez les petites organisations consultées durant cette enquête.

\subsection{Constat et continuité}

Cette investigation a permis, outres les résultats présentés, de recueillir des données utiles à la Chaire en génie de la conception de CRSNG-UQAR concernant les réalités de la conception en région tels :

- l'utilisation de logiciels de conception;

- l'acquisition d'équipements de production;

- la gestion de la production;

- le nombre de stagiaires embauchés;

- le manque de main-d'œuvre spécialisée;

- $\quad$ le recours à des programmes d'aide en R\&D;

- le partenariat avec des institutions;

- le rayonnement de la Chaire;

- des projets de conception pour les étudiants.

En ce qui concerne les derniers résultats présentés, cette enquête ne visait pas à évaluer la performance de la conception. C'est pourquoi on ne peut juger de l'adéquation du recours à des méthodes, outils et techniques de conception en fonction du processus de conception utilisé et des résultats recherchés par une entreprise.

Ainsi, ce portrait de la conception, a fait germer l'idée d'une continuation de l'investigation dans le cadre d'un projet de recherche au second cycle.

\section{Un nouveau projet de recherche}

À l'automne 2010, un projet de recherche visant à mieux connaître les pratiques de conception dans les entreprises susceptibles d'employer des finissants en génie et à définir des voies pour parfaire la culture de la conception chez les entreprises a été lancé.

Le nouveau projet de recherche consiste en une étude dont le but est de contribuer au développement d'un outil de caractérisation et d'évaluation de la pratique de la conception. Un de ces objectifs spécifiques est d'identifier les indicateurs de performance du processus de conception.

L'approche adoptée pour mener ce nouveau projet de recherche est une approche inductive. L'étude de cas particuliers d'entreprises pratiquant la conception aidera à formuler des généralisations, voire à élaborer de nouvelles hypothèses, notamment sur les variables appropriées pour mesurer la performance en conception. Vu le nombre de variables qui seront mesurées et le mandat exploratoire, l'échantillon devrait viser une trentaine de participants.

La recherche s'appuie sur des savoirs relatifs au 
domaine de la conception. Une revue de littérature supporte la construction d'un questionnaire destiné à mesurer les variables qui caractérisent les pratiques de conception et influencent sa performance.

Le questionnaire reprendra certaines questions de la recherche de l'hiver 2010 pour fin de caractérisation. Avant d'être utilisé pour les fins de la recherche, le questionnaire sera testé et affiné sur une base pilote. Cependant, l'approche sera différente et les variables seront évaluées quant à leur degré d'importance sur le succès des projets de conception par des chefs de projet. Pour ce faire, l'évaluation sera établie grâce à des échelles de Likert comprenant 7 degrés (essentiel au succès $=6$, pas d'influence sur le succès $=0$ ).

Le devis de cette recherche est aussi en partie descriptif puisque les données seront analysées afin de voir comment les variables sont liées et quelles sont celles qui contribuent le plus fortement au succès des projets de conception.

Les données recueillies seront traitées à l'aide d'analyses factorielles en composantes principales. Les analyses permettront d'identifier les facteurs les plus importants, ce qui conduira au développement d'indicateurs de performance en conception. Ceux-ci évalueront les différentes dimensions d'un projet de conception. Ils permettront d'évaluer la performance en conception en fonction des meilleures pratiques.

Une fois que les variables qui influencent le succès auront été identifiées, que les facteurs auront été composés, un nouveau questionnaire (outil de mesure) pourra être développé, celui-ci étant destiné à un plus grand nombre d'entreprises. Ce questionnaire constituera la base d'une recherche longitudinale, confiée à un organe de recherche, soit un observatoire des pratiques de conception.

\subsection{Revue de littérature}

Dans le cadre de cette nouvelle recherche, une revue de littérature a été effectuée afin d'établir les bases conceptuelles de la performance en conception.

Dans un premier temps, cette revue de littérature montre que la conception est motivée par différents [4] moteurs et qu'elle découle d'un contexte qui impose des adaptations et de l'innovation [14][17]. Ensuite, il est constaté que, selon les secteurs d'activités, les pratiques et les avantages attribués à la conception diffèrent [4][15].

La revue de littérature permet de préciser des concepts liés à la conception en ingénierie et notamment celui de processus de conception [1][11][12][13][19][20]. Enfin, elle permet de choisir un modèle qui convienne à la caractérisation et à l'évaluation des pratiques de conception [4][18]. Les lignes qui suivent présentent quelques éléments de cette revue.

\subsubsection{Moteurs de l'investissement en conception}

Le contexte de concurrence oblige les entreprises à être réactive et à anticiper l'évolution des technologies. C'est pourquoi les entreprises doivent non seulement maîtriser la qualité, le coût et le délai de mise sur le marché de leurs produits, mais aussi, leur flexibilité et leur réactivité pour performer [14].

Dans ce contexte, les entreprises doivent entre autres porter leur attention sur l'optimisation de leurs technologies et de leurs procédés de fabrication mais aussi de leurs méthodes de conception [17].

Pour les entreprises nord-américaines, l'évolution des préférences des clients et le resserrement des délais de mise en marché constituent les principaux moteurs de l'investissement en conception, mais on peut aussi citer l'accroissement des capacités et des performances des produits et de la technologie [4].

\subsubsection{Conception et secteurs d'activités}

Les buts et les avantages qui découlent de l'adoption de technologies de pointe et de procédés en conception diffèrent selon les secteurs d'activités.

Par exemple, chez les fabricants à faible intensité technologique, où l'innovation porte surtout sur les améliorations à apporter aux produits, l'impact des technologies de développement de produits sur l'innovation est fort [15].

Cependant, dans les secteurs de forte intensité technologique, caractérisés par un court cycle de vie des produits et par des entreprises très concurrentielles, l'impact de la R\&D de produits sur l'innovation est plus important que l'impact des technologies de développement de produits [15].

Il est observé que l'adoption de technologies de pointe en conception de produits comme le développement de produits virtuels et le prototypage rapide est plus fréquente et opportune dans certains secteurs d'activité que d'autres [4].

De même, le recours à un procédé de conception comme la conception/ingénierie simultanée s'observe plus fréquemment dans les secteurs d'activités où différents décideurs interviennent dans le processus de conception puisque cette approche facilite l'optimisation des différents paramètres de la conception comme la performance et le coût de fabrication du produit [4]. 


\subsubsection{Processus de conception}

Il existe de nombreuses définitions du processus de conception [3]. Cependant, on peut le définir comme un ensemble d'activités mises en œuvre (de façon séquentielle et/ou parallèle) utilisant des ressources humaines et matérielles pour satisfaire les objectifs de conception et aboutir à la définition du produit [14].

Bien que la conception soit difficile à modéliser de par sa dimension cognitive [6], plusieurs descriptions du processus de conception ont été proposées [8].

À ce titre, on peut citer les modèles développés sur la notion de phase tels que ceux de Pahl et Beitz [11], Pugh [12], Ulrich et Eppinger [20] et Ulman [19].

Ces modèles mettent en évidence qu'il faut s'attacher à planifier l'évolution du produit en ayant une vision allant du niveau global à un niveau très détaillé. La notion de phase considère les étapes du processus de conception comme étant jalonnées temporellement et définies par une planification hiérarchique à priori [14].

Il existe aussi une approche du processus de conception basée sur les activités. Le tableau 3 présente deux descriptions du processus de conception selon cette approche. La notion d'activité rend compte de l'accomplissement des tâches des acteurs du processus. La description du processus est basée sur une décomposition temporelle du déroulement des activités de conception et est organisée en unité d'action (acteur ou groupe affecté à un objectif).

Tableau 3. Activités du processus de conception

\begin{tabular}{|l|}
\hline MODĖLE Purcell [13] (Purcell, 94) \\
\hline - Analyser le problème \\
- Proposer une solution \\
- Analyser la solution \\
- Expliciter les stratégies \\
\hline MODĖLE Amhed [1] (Amhed, 02) \\
\hline - Spécifier \\
- Evaluer \\
- Valider \\
- Diriger, \\
- Unifier \\
- Décider \\
\hline
\end{tabular}

\subsubsection{Choix d'un modèle conceptuel}

Le processus de conception est un ensemble d'activités organisées pour satisfaire les objectifs de la conception dans un contexte spécifique. Ces objectifs concernent surtout la définition du produit. Ils sont dépendants de la structure de l'entreprise [10] et des différentes activités du processus de conception. Les objectifs sont aussi influencés par la technologie et par les ressources humaines et physiques [21].

En fonction du type de conception, les objets de la conception ne sont pas les mêmes. Lorsque le processus est routinier, le chef de projet décompose le projet en fonction des activités identifiées et les tâches des concepteurs sont alors assez prescrites [14][18]. Dans ces cas, le respect du délai constitue l'objectif de performance le plus important à atteindre. Le chef de projet décide de la synchronisation entre les ressources humaines et matérielles disponibles et les besoins des activités.

Dans d'autres cas, la conception est considérée comme un processus innovant. Les activités ne structurent pas le projet [18]. Le projet est alors organisé pour favoriser la collaboration entre les acteurs afin de faciliter l'émergence de solutions.

De nombreux modèles de description d'un projet ont été proposés [5][7][9] et une synthèse des différentes approches [18] montre que pour décrire le contexte dans lequel se déroule le processus de conception, on doit considérer les aspects humains, le savoir scientifique et technologique, de même que l'environnement socioéconomique et organisationnel. Cette synthèse est présentée à la figure 1 .

Figure 1. Modèle conceptuel du système de conception

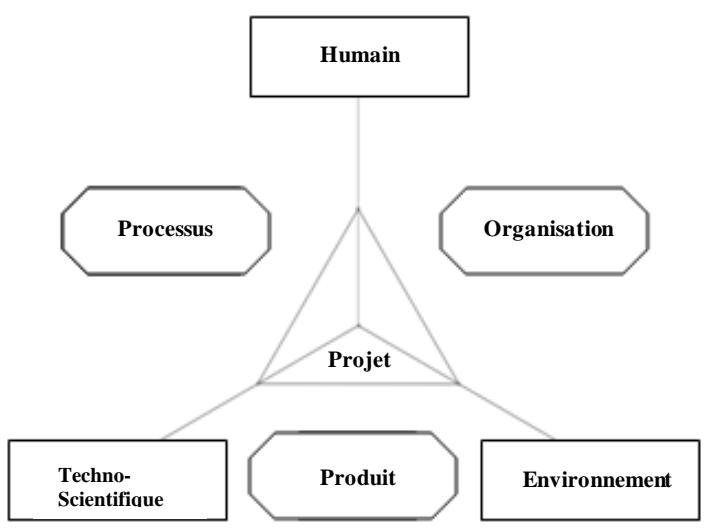

Dans ce modèle, l'axe des environnements interne et externe représentent l'entreprise et son environnement.

L'axe humain concerne les ressources humaines qui interviennent dans le projet.

L'axe techno-scientifique correspond aux savoirs et aux technologies présents dans l'entreprise.

Pour prendre en compte les interactions entre les axes d'un projet de conception, il est proposé de les appréhender par des aspects intermédiaires soit celui du produit, du processus et de l'organisation.

L'aspect produit se positionne entre les axes de l'environnement et celui du savoir car c'est par le 
produit que le savoir et la technologie sont démontrés et que l'entreprise peut performer dans un marché.

L'aspect processus se trouve entre le savoir et l'humain puisque c'est par le processus (phases et activités) que les acteurs transforment le savoir en un produit possédant telle ou telle caractéristique.

L'aspect organisationnel se situe entre les axes de l'environnement et de l'humain car au niveau organisationnel, le pilotage d'un projet de conception se traduit par l'affectation de ressources et par la mise en place d'une organisation adaptée à la situation.

\subsection{Opérationnalisation}

Les axes et les aspects doivent être caractérisés. Le questionnaire vise à identifier les facteurs importants et à développer des indicateurs de performance.

Pour l'environnement, il importe de connaître le secteur d'activité, les caractéristiques du marché, la taille de l'entreprise, son réseau. Les variables mesurées devraient constituer le facteur environnement d'un projet de conception.

Pour l'axe humain, il s'agit de connaître les acteurs impliqués, leurs compétences, leurs responsabilités, leurs rôles, leurs disponibilités. Ces variables devraient correspondre au facteur humain.

L'axe tecno-scientifique sera caractérisé par les technologies de pointe utilisées en conception, de même que par la R\&D, la capitalisation des savoirs et les domaines d'expertise de l'entreprise. Ces variables constitueront le facteur techno-scientifique.

L'aspect organisationnel, sera décrit en fonction de la gestion du projet de conception, soit la structure de gestion mise en place, la planification, l'attribution des ressources, les suivis et les contrôles. Ces variables constitueront le facteur organisationnel.

Le processus sera décrit à partir d'une liste de phases et d'activités découlant des modèles existants et par le recours à des méthodes, outils et techniques de conception. Ces variables constitueront le facteur processus.

Le produit sera caractérisé par sa complexité, son degré technologique, son caractère innovant afin de constituer le facteur produit.

Le questionnaire servira à collecter de l'information sur les systèmes de conception de l'entreprise et à mesurer l'importance des différentes variables sur le succès des projets de conception. Ainsi, il sera possible de cartographier le système de conception des entreprises et d'identifier les variables et les facteurs primordiaux.

Puisque le secteur d'activité influence la pratique de la conception, les entreprises sondées seront choisies dans 5 secteurs d'activité et l'échantillon visera une trentaine d'entreprises, reconnues pour la qualité de leurs produits et leur leadership.

\section{Vers un observatoire de la conception}

Ce dernier point traite de la mise en place d'un observatoire des pratiques de conception dans les entreprises. Le projet de recherche présenté au point précédent et l'implantation de l'observatoire concourent à développer un outil de caractérisation et d'évaluation du processus de conception. L'observatoire veillera à l'affinement de l'outil développé dans le projet de recherche et pourra fournir des données pour des recherches reliées.

Spécifiquement, les objectifs de cet observatoire seront de :

- $\quad$ suivre l'évolution de la pratique de la conception en entreprise;

- améliorer la formation offerte en enseignant comment agir sur les facteurs déterminants;

- développer des outils de diagnostics;

- $\quad$ supporter l'amélioration continue des processus de conception.

Le modèle conceptuel de cet observatoire est établi. Il sera basé sur les trois dimensions et les trois aspects qui permettent d'identifier le système de conception spécifique à chaque entreprise.

L'observatoire jouera un rôle au niveau structurel, en fournissant de l'information aux acteurs comme les entreprises participantes, les institutions d'enseignement, les organismes de développement économique.

Quant aux ressources humaines, l'observatoire favorisera le développement des compétences en conception de futurs ingénieurs en s'assurant que les contenus des programmes sont adaptés aux besoins en conception et que les compétences acquises par les ingénieurs en formation profitent aux entreprises. De plus, il contribuera à l'appropriation de la culture de la conception chez les acteurs par des interventions ciblées.

Enfin, l'observatoire jouera un rôle stratégique en initiant une synergie entre les entreprises et les acteurs de développement en ce qui concerne la conception. Ce faisant, il favorisera le développement de partenariats dans un but de support afin d'améliorer les performances en conception et d'aider à la consolidation et au développement des entreprises participantes.

Avec sa double capacité d'information et d'expertise, cet observatoire devrait permettre, à terme, de disposer de données techniques pour un ensemble considérable d'entreprises. Il pourra ainsi soutenir les décideurs et acteurs tant régionaux que nationaux dans leurs décisions stratégiques. 


\section{Références}

[1] P.K. Ahmed, K.K. Lim, M. Zairi, « Measurement practice for knowledge management », Journal of Workplace Learning, Vol.11, N 8, pp. 304-311, 1999.

[2] CEAB: Canadian Engineering Accreditation Board, Accreditation criteria and procedures, 2007.

[3] D. Deneux, « Méthodes et Modèles pour la conception concourrante », Habilitation à Diriger des Recherches, Université de Valenciennes et du Hainaut Cambrésis, 24 Jan 2002.

[4] DESIGN EXCHANGE en collaboration avec Manufacturiers et exportateurs du Canada et Industrie Canada, «L'ÉTAT de la CONCEPTION DE PRODUITS: LE RAPPORT CANADIEN $2010 », 2010$.

[5] E. Eder, «Integration of theories to assist practice », 5th International Conference on Integrated Design and Manufacturing in Mechanical Engineering, IDMME04, Bath, 2004.

[6] J.S. Gero, "An approach to the analysis of design protocols », Design studies, Vol. 19, №1, pp. 21-61, 1998

[7] H. Laurikkala, E. Puustinen, E. Pajarre, K. Tanskanen, " Reducing complexity of modelling in large delivery projects », 13th International Conference on Engineering Design, ICED01, Glasgow, 2001.

[8] T. Love, «Philosophy of design: a meta-theoretical structure for design theory », Design Studies, Vol. 21, N³, pp. 293-313, 2000.

[9] F. Marle, « Modèles d'informations et méthodes pour aider à la prise de décision en management de projet » Thèse Ecole Centrale de Paris, 2002.

[10] H. Mintzberg, Le management : voyage au centre des organisations, Les Éditions d'Organisation, 1989.
[11] G. Pahl, and W. Beitz, Engineering Design - A Systematic Approach, Springer, New York, USA, 1996.

[12] S. Pugh, Total design, integrated methods for successful product engineering, Addison-Wesley, 1990.

[13] T. Purcell, J. Gero, H. Edwards, E. Matka, « Design fixation and intelligent design aids ", in Artificial Intelligence in Design, J.S.Gero and F. Sudweeks (ed.), Kluwer, 1994.

[14] V. Robin, « Évaluation de la performance des systèmes de conception pour la conduite de l'ingénierie des produits ; prototype logiciel d'aide aux acteurs », Thèse doctorale, Université Bordeaux 1, École des sciences doctorales des sciences physiques et de l'ingénieur, 2005.

[15] L. Raymond, J. St-Pierre, « La R\&D en tant que déterminant de l'innovation dans les PME : Essai de clarification empirique », Retour aux communications, $5^{\mathrm{e}}$ Congrès International de l'Académie de l'Entreprenariat, 2007.

[16] G. Sohlenius, « Concurrent Engineering », Annals of the CIRP, Vol. N 41, 1992.

[17] J.C. Tarondeau, Stratégie Industrielle, Vuibert, Paris, 1993.

[18] G. Topliceanu G., V. Robin, C. Ispas, P. Girard, « Évaluation de la performance des processus collaboratifs en conception de produits », U.P.B. Sci. Bull., Series D, Vol. $\mathrm{N}^{\circ} 72$, Iss. 3, 2010 .

[19] D. Ullman, The Mechanical Design Process, McGrawHill, Inc., New York, NY, 1992.

[20] K.T. Ulrich, S.D. Eppinger, Product design and development, $2^{\text {nd }}$ edition, McGraw Hill International editions, 2000.

[21] F. Wang, J.J. Mills, V. Devarajan, « A conceptual approach managing design resource », Computers in Industry, Vol. $\mathrm{N}^{\circ} 47$, pp. 169-183, 2002. 